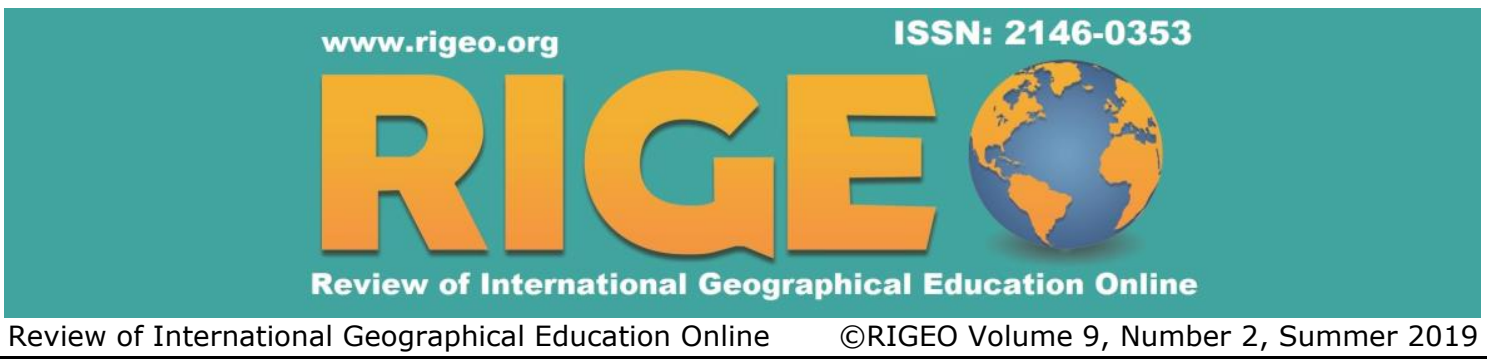

Research Article

Copyright @ RIGEO 2019

To cite this article: Hanifah, M., Mohmadisa, H., Yazid, S, Nasir, N., Balkhis, N., S. (2019). Professional and pedagogical competencies of form six geography teachers in malaysia. Review of International Geographical Education Online (RIGEO), 9(2), 304-318. Retrieved from http://www.rigeo.org/vol9no2/Number2Summer/RIGEO-V9-N2-3.pdf

DOI: $10.33403 /$ rigeo.509836

Submitted: January 8, 2019 Revised: March 13, 2019 Accepted: June 18, 2019

\title{
Professional and Pedagogical Competencies of Geography Teachers in Malaysia
}

\author{
Mahat HANIFAH ${ }^{1}$ \\ University Pendidikan Sultan Idris, MALAYSIA \\ Hashim MOHMADISA 2 \\ University Pendidikan Sultan Idris, MALAYSIA \\ Saleh YAZID ${ }^{3}$ \\ University Pendidikan Sultan Idris, MALAYSIA \\ Nayan NASIR ${ }^{4}$ \\ University Pendidikan Sultan Idris, MALAYSIA \\ Norkhaidi Saiyidatina BALKHIS ${ }^{5}$ \\ University Pendidikan Sultan Idris, MALAYSIA
}

\begin{abstract}
This study aims to examine the professional and pedagogical competencies of form six geography teachers in Malaysia. Study involved 200 geography teachers from across Malaysia, separated into five zones; the Northern Zone, the Central Zone, the East Coast Zone, the Southern Zone and the East Malaysia Zone. A questionnaire was used to collect the data. The six variables of professional and pedagogical competence studied were as follows: teachers' understanding of their topics, professional knowledge, subject content knowledge, pedagogical content knowledge, pedagogical technology knowledge and professional values. The findings showed all competencies of professionalism and pedagogy to be at high levels. Specifically, correlations revealed teachers' understanding of topics to
\end{abstract}

${ }^{1}$ Corresponding author: Department of Geography \& Environment, Universiti Pendidikan Sultan Idris, Malaysia. hanifah.mahat [at]fsk.upsi.edu.my , http://orcid.org/0000-0003-0756-6907

2Department of Geography \& Environment, Universiti Pendidikan Sultan Idris,Malaysia, mohmadisat [at] fsk.upsi.edu.my, https://orcid.org/0000-0001-6364-7918

32Department of Geography \&Environment, Universiti Pendidikan Sultan Idris, Malaysia. yazid [at] fsk.upsi.edu.my, https://orcid.org/0000-0003-1603-9025

${ }^{4}$ Associate Professor, Department of Geography \& Environment, Universiti Pendidikan Sultan Idris, Malaysia. nasir [at] fsk.upsi.edu.my , https://orcid.org/0000-0001-8812-4320

5Department of Geography and Environment, Universiti Pendidikan Sultan Idris, 35900, Tanjong Malim, Perak, Malaysia. balkhis86 [at] gmail.com, https://orcid.org/0000-0002-4571-4619

(C) Review of International Geographical Education Online RIGEO 2019 ISSN: 2146-0353 
have strong, significant relationships with their subject content knowledge, pedagogical content knowledge and pedagogical technology knowledge, and moderate, significant relationships with their professional knowledge and values. Hence, the results indicate that teachers' professional knowledge and values need to be enhanced in order to achieve the ideal level of professional and pedagogical competence for form six geography teachers in Malaysia.

\section{Keywords}

Competence; Professionalism; Pedagogy; Teachers; Geography

Education in Malaysia aims to create balanced and harmonious humans in terms of their physical, emotional, spiritual and intellectual development, through its curriculum and co-curricular activities. This goal is based on Malaysia's National Education Philosophy, which is not just a documentation of national aspirations but the core of its entire education system. This education philosophy directs all national education programmes and activities (Wan Mohd Zahid, 1991). Its implementation and realisation impose comprehensive implications on all parties, particularly the national education system. Any changes to the nation's education system, especially aspects of curriculum development, the provision of educators, educational institutions and other parties, must all be aligned with the education philosophy and government policies as stated in value oriented theory and content oriented theory in curriculum theory (Schiro, 2007).

Education in Malaysia is also dynamic, open to the current environment as well as future change in demands. National education has undergone a series of evaluations by several committees set up since 1950, culminating in the Murad Committee established in 2004 to study the need to empower national schools. This shows that the evaluation system is continuously subjected to a re-assessment and review process aimed at improving and upgrading the quality of education in the country. The main purpose of the assessments and reviews is to determine the effectiveness of implemented plans, including teaching and learning in the field of geography.

The issue of geography teaching and learning in schools and higher learning institutions has been a key one for some time (Nazli, 2009). Functional geography knowledge refers to the application of geographic and related skills to problem solving efforts in the environment. The acquisition of professional qualification and related skills in Geography equips an individual for self employment and related business opportunities for the future (Samuel et al., 2014). Moreover, with the advancement of science and technology, the field of geography continues to expand in line with the needs of human beings worldwideHowever, in Malaysia the situation has changed since geography received full status as an elective subject in 1993 (Chuah, Wan Rozali, \& Joseph, 2013). Since that time, geography as a subject has become isolated in Malaysia education system, affecting higher learning institutions. Nevertheless, various steps have been and are being taken by geography education practitioners to attract students using the teaching and learning method.

In addition, today teacher competence is a necessity if society and the country is to move forward in line with changing times. However, a paper by Saedah and Mohammed Sani (2012) has indicated that non-existent, comparable standards of education in Malaysia can be related to service problems, work stress, role conflict, 
unclear roles and the absence of social support systems for principals and co-workers. This has led to teachers resigning or retiring early through burnout. This situation has had a detrimental effect on the quality of our national education.

Even after the Ministry of Education (MOE) in 2013 established the aim of raising general teacher competence to tackle this issue, the problems discussed here are still being experienced by teachers. This clearly suggests the need for a detailed study not just of the general teaching competence of teachers but also of their competence in their own subject areas. This kind of study is necessary so that an ideal model of competence for the subject of geography can be produced. Such a model should include aspects of geography knowledge and skills as well as components of professional competencies set by the Ministry of Education Malaysia. Furthermore, geography teachers' competence in teaching two basic subject areas, namely physical geography and human geography, should be examined; both areas should be well-mastered by form six teachers in line with the development of non-static geography knowledge. Knowledge in geography teaching involves teaching knowledge, curriculum knowledge, knowledge organisation and knowledge of approaches to the teaching of geography that are necessary for geography teachers (Karademir, 2016).

Directly studying the competence of secondary school geography teachers still fails to attract the attention of researchers today (Nazli, 2009). But this does not mean that it should be ignored. Here, aspects of the professionalism and pedagogy of geography teachers are examined in order to develop a model that can assess the weaknesses of teachers that directly affect student achievement, which can in turn be addressed by creating a model of teacher competence. In this respect, the government's efforts to produce world-class Malaysian education is a good starting point for examining aspects of the professionalism, subject content knowledge, pedagogical content knowledge, pedagogical technology knowledge, attitudes and values of form six geography teachers, through teacher competence studies.

\section{Teacher Competence in Malaysia}

In Malaysia, the desire for efficient, high-quality teachers has been translated into various programmes, starting with the selection of future teachers, their training, induction and continuous professional development, up to the evaluation stage and performance management of the teachers themselves. However, in order to realise this desire, a clear standard must be established. To this end, the Malaysian Teacher Standards (SGM) set out the general professional competencies that teachers should demonstrate, with targets (standards) to be achieved by teachers and aspect statements to be prepared and implemented by the agency and institutional training institutes (requirements) (The Malaysian Teacher Standards, 2009). The SGM specifically assesses three standards, namely professional values in teaching practice, knowledge and understanding, and teaching and learning skills.

These standards can be seen as the criteria for the minimum competence to be demonstrated by teachers in their work. Teacher competence can be interpreted as the ability or efficiency of an individual to carry out their tasks, the ability of a teacher to 
impart knowledge through education (Zaiha, 2014) or the ability in terms of knowledge, personality and skills to carry out tasks excellently and effectively (Mohd Faiz \& Jamal, 2016). Teacher competence can be divided into four dimensions: pedagogical competence, personality competence, social competence and professional competence (Saedah \& Mohammed Sani, 2012). The first dimension, pedagogical competence, can be defined as a teacher's knowledge of how to convey knowledge and skills to students. Here, teachers need to know the best way to teach, how to manage classes, how to select appropriate teaching methods and how to use technology appropriately. With regard to the second dimension, teachers with personality competence are more likely to improve their level of professionalism by continuously conducting self-assessment and analysis (Saedah \& Mohammed Sani, 2012). The third dimension that of social competence, refers to a teacher's ability and skills to interact and communicate with the community. Communication and interaction can occur either through oral or written texts, the use of technology being strongly encouraged to ensure their effectiveness. Finally, the fourth dimension, professional competence, is defined as the ability or skills to devise and implement learning processes. To ensure effective teaching and learning processes, teachers must understand the component and structure of the field they are teaching as well as be able to assess and apply learning theory prudently (Saedah \& Mohammed Sani, 2012).

Competence can also be understood in the form of the Iceberg Competency Model introduced by Lyle and Signe (1993). This model is divided into two sections, as shown in Figure 1-in the first section knowledge and skills sit above the water level on ice blocks, while in the second the behavioural component that represents the characteristics of values, social role, self-image and nature is shown below the water level.

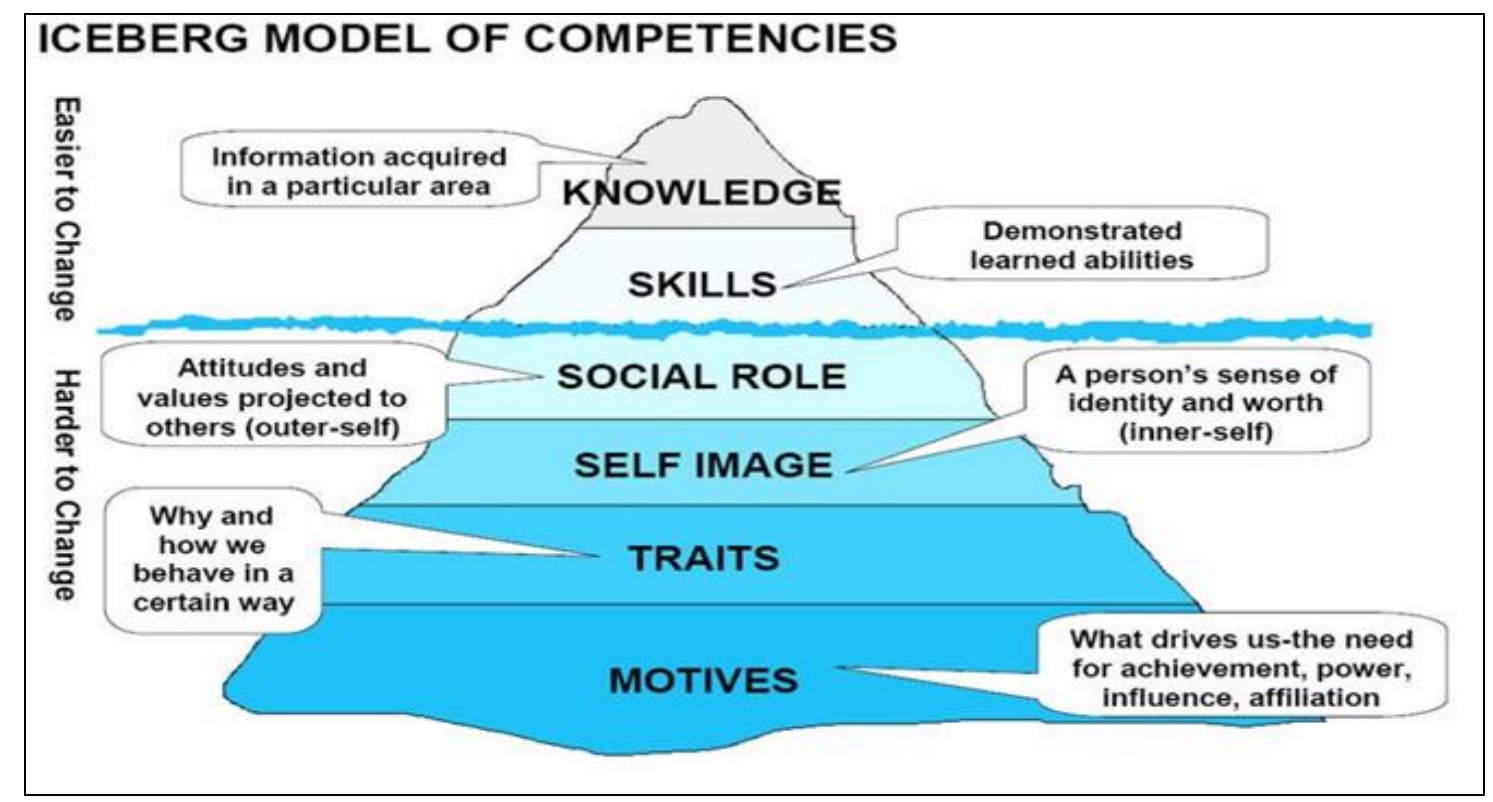

Figure 1. Iceberg Competency Model. Source: Lyle \& Signe (1993) 
Competence is also closely related to teachers' mastery of the contents of their subject, alongside professional knowledge, subject content knowledge, pedagogical content knowledge, pedagogical technology knowledge and professional values. According to Ahmad Yunus and Ab. Halim (2010), the mastery and understanding of subject content among teachers is important to ensure the effectiveness of teaching and learning. The findings of Mohammad Rusdi (2017) also showed that pedagogical content knowledge is related to understanding a subject, because a teacher's understanding of the subject content is different from that of subject content experts. That pedagogical technology knowledge is also important in improving the competence of teachers is in accordance with the opinion of Koehler et al. (2013), who argued that teachers should employ technology in teaching and lear sessions creatively and 'think outside the box' at the same time as mastering their teaching subject.

The study of the professional and pedagogical competencies of form six geography teachers in Malaysia is crucial for identifying the level of competence of teaching and learning geography teachers at the pre-university level (Suseela \& Sim, 2010). Geography has a close connection to humans and the environment - through its branches of human and physical geography. It is also seen as an important component of human life because it can instantly foster a spirit of love for the environment, whether locally or globally (Hanifah et al., 2015; Mohd Faris, Mohmadisa, \& Mohd Suhaily Yusry, 2013).

\section{Methodology}

According to Malaysia Ministry of Education (2018) data, there were 360 geography teachers that teaching geography at pre-university level. The recommended minimum number of samples selected is 185 people based on the Krijie and Morgan charts, (1971). Therefore, a total of 200 geography teachers were selected as study samples using a cluster sampling technique according to zones: 40 participants each came from the Northern Zone (Perlis, Kedah, Penang, Perak); the Central Zone (Selangor, Kuala Lumpur, Putrajaya); the East Coast Zone (Kelantan, Terengganu, Pahang); the Southern Zone (Melaka, Negeri Sembilan, Johor); and the East Malaysia Zone (Sabah, Sarawak) (Table 1).

Table 1

Study Samples of Form Six Geography Teachers by Zone

\begin{tabular}{lc}
\hline \multicolumn{1}{c}{ Location } & Number of Sample \\
\hline Northern Zone (Perlis, Kedah, Pulau Pinang) & 40 \\
Central Zone (Perak, Selangor) & 40 \\
East Coast Zone (Kelantan, Terengganu dan Pahang) & 40 \\
Southern Zone (Negeri Sembilan, Melaka, Johor) & 40 \\
East Malaysia Zone (Sabah, Sarawak) & 40 \\
Total & $\mathbf{2 0 0}$ \\
\hline
\end{tabular}

\section{Study Instruments}

This study's research instrument was a questionnaire containing seven sections from difference sources (see Table 2). Section A captured respondents' demographic information while Section B covered information on their understanding of form six geography topics. The form six geography topics examined here consisted of topics in the form six Sijil Tinggi Pelajaran Malaysia (STPM) Geography syllabus that divided into four papers. Paper 1 was divided into two sections, Physical Geography and Human 
Geography, and covered four main topics: Earth System, Geomorphology System, Population and Village Transformation and Urbanization. Paper 2 was also divided into two sections, Physical Geography and Human Geography, and covered the following four main topics: Atmospheric Systems, Hydrological Systems, Economic Development and Environmental Impacts and Globalization of Economics and Regional Cooperation. Again, Paper 3 was divided into two sections, Physical Geography and Human Geography, and covered three main topics: Ecological System, Integration System and Environmental Impact and Management. Finally, Paper 4 represented Section C of the syllabus, Field Work, and was broken down into six sections: Introdution to Field Work, Field Work Method, Field Work Implementation, Data Processing and Analysis, Report Preparation and Report Presentation.

Sections C, D, E, F and G captured information on the teachers' competence, including professional knowledge, subject content knowledge, pedagogical content knowledge, pedagogical technology knowledge, and professional values. Item in professional knowledge asking more about teacher's knowledge in teaching strategies to be implemented in the classroom. Subject content knowledge are more too measure teacher knowledge of subjects to be studied or will be taught. While pedagogical content knowledge asking more about teacher understanding of the process or teaching method. Items in pedagogical technology knowledge were measured in teacher knowledge to create an active learning environment by using existing and new technologies in the school environment. Finally a professional values items measure techer in maintaining the profession's value as an educator to be respected and respected by society.

Table 2

Respondent Questionnaire Information

\begin{tabular}{|c|c|c|c|c|}
\hline Section & Details & Variables & $\begin{array}{l}\text { Number } \\
\text { of Items }\end{array}$ & Source \\
\hline \multirow{6}{*}{ A } & \multirow{6}{*}{$\begin{array}{l}\text { Background of } \\
\text { Teacher }\end{array}$} & State & 1 & \multirow{6}{*}{$\begin{array}{l}\text { Self-built according to } \\
\text { the needs of the study }\end{array}$} \\
\hline & & Location & 2 & \\
\hline & & Age & 1 & \\
\hline & & Gender & 2 & \\
\hline & & Races & 7 & \\
\hline & & Teaching Experience & 1 & \\
\hline \multirow{9}{*}{ B } & \multirow{9}{*}{$\begin{array}{l}\text { Teachers' } \\
\text { Understanding } \\
\text { of Topics }\end{array}$} & $\begin{array}{l}\text { Paper 1: Part A } \\
\text { Physical Geography }\end{array}$ & 10 & \multirow{9}{*}{$\begin{array}{l}\text { Built and modified from } \\
\text { Form Six Geography } \\
\text { Syllabus, Malaysia } \\
\text { Ministry of Education } \\
\text { (2018) }\end{array}$} \\
\hline & & Paper 1: Part B & \multirow{2}{*}{7} & \\
\hline & & $\begin{array}{l}\text { Human Geography } \\
\text { Paper 2. Part A }\end{array}$ & & \\
\hline & & $\begin{array}{l}\text { Paper 2: Part A } \\
\text { Physical Geography }\end{array}$ & 12 & \\
\hline & & Paper 2: Part B & \multirow{2}{*}{7} & \\
\hline & & Human Geography & & \\
\hline & & $\begin{array}{l}\text { Paper 3: Part A } \\
\text { Physical Geooraphy }\end{array}$ & 7 & \\
\hline & & Paper 3: Part B & \multirow{2}{*}{3} & \\
\hline & & Human Geography & & \\
\hline
\end{tabular}


Hanifah, M., Mohmadisa, H., Yazid, S, Nasir, N., Balkhis, N., S. (2019) / Professional and pedagogical....

Paper 4: Part C

Field Work

C Professional Knowledge

D Subject Content Knowledge

E Pedagogical Knowledge

F Pedagogical Technology Knowledge

G Professionalism Value
6

16

Built and modified from

Malaysia Teacher

Standard

Built and modified from

Malaysian Examination

13 Council (2012). Sijil

Tinggi Pelajaran

Malaysia (STPM).

12

Built and modified from

Shulman (1987)

Built and modified from

10 Mohammad Rusdi and

Ab Majid (2017)

Built and modified from

Malaysian Examination

13 Council (2012). Sijil

Tinggi Pelajaran

Malaysia (STPM)

\section{Validity and Reliability of the Questionnaire}

A draft questionnaire has been developed through a validity process. Face validity by Bhattacherjee (2012) refers to whether an indicator seem to be reasonable measure of its underlying construct "on its face". Sabitha (2006) also debates the same thing and adds to form the validity of the face, the experience can be used. Thus, in this study, the process of legitimacy to get respondents' views regarding the competency of Form Six Geography teachers involves three of Form Six Geography teachers themselves. Their views and comments are used to improve the questionnaire. Table 3 shows the reliability of the teacher competence variables - teachers' understanding of topics, their professional knowledge, subject content knowledge, pedagogical content knowledge, pedagogical technology knowledge and professional values-with Cronbach's Alpha value used to measure their internal consistency. According to Babbie (1992), Cronbach's Alpha values are classified according to a reliability index where values of 0.90 until 1.00 are considered very high, 0.70 until 0.89 high, 0.30 until 0.69 moderate and 0.00 until 0.30 are considered low. The results of the analysis showed the Cronbach's Alpha value to be in the 'very high' classification, above 0.90 . The questionnaire used in this study therefore has a very high reliability according to Babbie's (1992) classification and is suitable as a research instrument.

Table 3

The Reliability Values

\begin{tabular}{lcc}
\multicolumn{1}{c}{ Variables } & No. of Item & Alpha Cronbach Value \\
\hline Teachers' Understanding of Topics & 52 & 0.986 \\
Professional Knowledge & 16 & 0.953 \\
Subject Content Knowledge & 13 & 0.949 \\
Pedagogical Knowledge & 12 & 0.954 \\
Pedagogical Technology Knowledge & 10 & 0.925
\end{tabular}




\begin{tabular}{lll} 
Professionalism Value & 13 & 0.957 \\
\hline
\end{tabular}

\section{Results and Discussion}

\section{Teachers' Demographic Background}

Table 4 shows the demographic background of the 200 teachers who participated in the study. In terms of location, 97 respondents (48.5\%) taught in schools in urban areas, while the remaining $103(51.5 \%)$ taught in schools in rural areas. The highest proportion of respondents was aged between 46 and 50 years (a total of 66 people or 33.0\%). The next most populous category was 51 to 55 years (46 people or $23.0 \%$ ), followed by 41 to 45 years ( 41 people or $20.5 \%$ ), 36 to 40 years ( 26 people or $13.0 \%$ ), 31 to 35 years (11 people or $5.5 \%$ ), above 56 years (six people or $3.0 \%$ ) and below 30 years (four people or $2.0 \%)$. As for the gender of respondents, 77 (38.5\%) were male, $123(61.5 \%)$ female. With regard to race, $124(62.0 \%)$ were Malay, $26(13.0 \%)$ were Chinese, 13 (6.5\%) were Indian, seven (3.5\%) were Sarawak Bumiputera, 27 (13.5\%) were Sabah Bumiputera, one was Siamese $(0.5 \%)$ and two was Bugis $(1.0 \%)$. Regarding education qualifications, two of the respondents had the highest degree of doctor of philosophy $(\mathrm{PhD})(1.0 \%), 31$ had a master's degree $(15.5 \%)$ and 176 a bachelor's degree $(83.5 \%)$. In terms of teaching experience, three teachers $(1.5 \%)$ had taught for fewer than five years, while $11(5.5 \%)$ had taught for six to 10 years, $26(13.0 \%)$ for 11 to 15 years, $56(28 \%)$ for 16 to 20 years, six $(30.5 \%)$ for 21 to 25 years, $36(18.0 \%)$ for 26 to 30 years and seven $(3.5 \%)$ for more than 31 years.

Table 4

Respondents' Demographic Background

\begin{tabular}{llcc}
\hline Respondents' Demographic Background & N & Percentage (\%) \\
\multirow{3}{*}{ Location } & Urban & 97 & 48.5 \\
& Rural & 103 & 51.5 \\
& Total & $\mathbf{2 0 0}$ & $\mathbf{1 0 0}$ \\
& Less than 30 years old & 4 & \\
& 31 until 35 years old & 11 & 2.0 \\
& 36 until 40 years old & 26 & 5.5 \\
Age & 41 until 45 years old & 41 & 13.0 \\
& 46 until 50 years old & 66 & 20.5 \\
& 51 until 55 years old & 46 & 33.0 \\
& More than 56 years old & 6 & 23.0 \\
& Total & $\mathbf{2 0 0}$ & 3.0 \\
Gender & & 77 & $\mathbf{1 0 0}$ \\
& Male & 123 & 38.5 \\
& Female & $\mathbf{2 0 0}$ & 61.5 \\
& Total & 124 & $\mathbf{1 0 0}$ \\
\multirow{4}{*}{ Race } & Malay & 26 & 62.0 \\
& Chinese & 13 & 13.0 \\
& Indian & 7 & 6.5 \\
& Sarawak Bumiputera & 27 & 3.5 \\
& Sabah Bumiputera & & 13.5
\end{tabular}




\begin{tabular}{llcc} 
& Siamese & 1 & .5 \\
& Bugis & 2 & 1.0 \\
& Total & $\mathbf{2 0 0}$ & $\mathbf{1 0 0}$ \\
Education & Doctorate $(\mathrm{PhD})$ & 2 & 1.0 \\
Qualifications & Master Degree & 31 & 15.5 \\
& Bachelor Degree & 167 & 83.5 \\
& Total & $\mathbf{2 0 0}$ & $\mathbf{1 0 0}$ \\
& Less than 5 years old & 3 & 1.5 \\
AgesTea & 6 until 10 years old & 11 & 5.5 \\
& 11 until 15 years old & 26 & 13.0 \\
& 16 until 20 years old & 56 & 28.0 \\
& 21 until 25 years old & 61 & 30.5 \\
& 26 until 30 years old & 76 & 18.0 \\
& More than 31 years old & $\mathbf{2 0 0}$ & 3.5 \\
& Total & $\mathbf{1 0 0}$ \\
\hline
\end{tabular}

\section{Teachers' Level of Understanding of Form Six Geography Topics}

To facilitate interpretation of the levels of teachers' understanding, the cut-off point by Landell (1997) was used (Table 5).

Table 5

Cut-off Point of the Levels of each Study Variable

\begin{tabular}{lc}
\hline \multicolumn{1}{c}{ Scale } & Level \\
\hline Score $1.00-2.33$ & Low \\
Score $2.34-3.66$ & Medium \\
Score $3.67-5.00$ & High \\
\hline
\end{tabular}

Source: Landell (1997)

Table 6 shows the levels of teachers' understanding of the form six geography topics. The results show that the overall level of the variables was high were the value of mean are more than 4.00. This indicates that the level of teachers' understanding of form six geography topics was very good and satisfactory. 
Table 6

Teachers' Level of Understanding of Form Six Geography Topics

\begin{tabular}{|c|c|c|c|c|c|c|c|c|c|c|c|}
\hline \multirow[t]{2}{*}{$\begin{array}{c}\text { Pape } \\
\mathbf{r}\end{array}$} & \multirow[t]{2}{*}{ Part } & \multirow[t]{2}{*}{ Variables } & \multicolumn{2}{|c|}{$\begin{array}{l}\text { Low } \\
\text { Level }\end{array}$} & \multicolumn{2}{|c|}{$\begin{array}{l}\text { Medium } \\
\text { Level }\end{array}$} & \multicolumn{2}{|c|}{ High Level } & \multirow[t]{2}{*}{$\begin{array}{c}\text { Mea } \\
\mathbf{n}\end{array}$} & \multirow[t]{2}{*}{ SD } & \multirow{2}{*}{$\begin{array}{c}\text { Level } \\
\text { of } \\
\text { Mean }\end{array}$} \\
\hline & & & $\mathbf{N}$ & $\%$ & $\mathbf{N}$ & $\%$ & $\mathbf{N}$ & $\%$ & & & \\
\hline \multicolumn{3}{|l|}{ Overall } & 1 & 0.5 & 0 & 0 & 199 & 99.5 & 4.110 & 0.573 & High \\
\hline \multirow[t]{5}{*}{1} & & Earth & 4 & 2.0 & 4 & 2.0 & 192 & 96.0 & 4.072 & 0.702 & High \\
\hline & $\begin{array}{l}\text { Part A: } \\
\text { Physical } \\
\text { Geography }\end{array}$ & $\begin{array}{l}\text { System, } \\
\text { Geomorpholo } \\
\text { gy System }\end{array}$ & 3 & 1.5 & 5 & 2.5 & 192 & 96.0 & 4.045 & 0.678 & High \\
\hline & & Population & 1 & 0.5 & 1 & 0.5 & 198 & 99.0 & 4.311 & 0.624 & High \\
\hline & Part B: & Village & 6 & 3.0 & 1 & 0.5 & 193 & 96.5 & 4.023 & 0.747 & High \\
\hline & $\begin{array}{l}\text { Human } \\
\text { Geography }\end{array}$ & $\begin{array}{l}\text { Transformati } \\
\text { on and } \\
\text { Urbanization }\end{array}$ & & & & & & & & & \\
\hline \multirow[t]{5}{*}{2} & Part A: & $\begin{array}{l}\text { Atmospheric } \\
\text { Systems }\end{array}$ & 3 & 1.5 & 6 & 3.0 & 191 & 95.5 & 4.059 & 0.688 & High \\
\hline & $\begin{array}{l}\text { Physical } \\
\text { Geography }\end{array}$ & $\begin{array}{l}\text { Hydrological } \\
\text { Systems }\end{array}$ & 5 & 2.5 & 1 & 0.5 & 194 & 97.0 & 4.103 & 0.704 & High \\
\hline & & $\begin{array}{l}\text { Economic } \\
\text { Development }\end{array}$ & 1 & 0.5 & 4 & 2.0 & 195 & 97.5 & 4.258 & 0.654 & High \\
\hline & $\begin{array}{l}\text { Part B: } \\
\text { Human }\end{array}$ & $\begin{array}{l}\text { Environment } \\
\text { al Impacts } \\
\text { and }\end{array}$ & 4 & 2.0 & 0.0 & 0.0 & 196 & 98.0 & 3.869 & 0.748 & High \\
\hline & Geography & $\begin{array}{l}\text { Globalization } \\
\text { of Economics } \\
\text { and Regional } \\
\text { Cooperation }\end{array}$ & & & & & & & & & \\
\hline \multirow[t]{3}{*}{3} & Part A: & $\begin{array}{l}\text { Ecological } \\
\text { System }\end{array}$ & 6 & 3.0 & 0.0 & 0.0 & 194 & 97.0 & 4.084 & 0.698 & High \\
\hline & $\begin{array}{l}\text { Physical } \\
\text { Geography }\end{array}$ & $\begin{array}{l}\text { Integration } \\
\text { System }\end{array}$ & 8 & 4.0 & 1 & 0.5 & 191 & 95.5 & 4.097 & 0.742 & High \\
\hline & $\begin{array}{l}\text { Part B: } \\
\text { Human } \\
\text { Geography }\end{array}$ & $\begin{array}{l}\text { Environment } \\
\text { al Impact and } \\
\text { Management }\end{array}$ & 3 & 1.5 & 2 & 1.0 & 195 & 97.5 & 4.245 & 0.653 & High \\
\hline 4 & Field Work & & 2 & 1.0 & 0.0 & 0.0 & 198 & 99.0 & 4.160 & 0.669 & High \\
\hline
\end{tabular}

\section{Teachers' Level of Competence}

Table 7 shows the level of competence of the teachers across five variables, namely Professional Knowledge (PPP), Subject Content Knowledge (PKS), Pedagogical Content Knowledge (PPK), Pedagogical Technology Knowledge (PTP), and Professional Values (NPK). In order to facilitate interpretation of the levels for each variable we divided the levels into three, namely lower, medium and high, as previously described in Table 5. The findings show that overall variable levels were high, with mean values within the range of 4.128 to 4.515 . This shows that the level of competence of form six geography teachers in Malaysia was very good and satisfactory. These results are in line with those of Anuar and Nelson (2015), who found the majority of teachers in their study to have high teacher competence as measured by their skills of diversifying teaching strategies, carrying out learning assessments and using information technology. However, the findings of Hasnah and Jamaludin (2017) 
showed teachers' competence in understanding and knowledge to be of only moderate level. Generally, teacher competence varies according to the subject and is influenced by demographic as well as internal factors, such as support from school administrative organisations, adequate training and efficient time management (Rohayati, Ahmad Fauzi, \& Othman, 2012).

Table 7

The Level of Competence of Form Six Geography Teachers in Malaysia

\begin{tabular}{|c|c|c|c|c|c|c|c|c|c|}
\hline \multirow{2}{*}{ Variables } & \multicolumn{2}{|c|}{ Low Level } & \multicolumn{2}{|c|}{ Medium Level } & \multicolumn{2}{|c|}{ High Level } & \multirow[t]{2}{*}{ Mean } & \multirow[t]{2}{*}{ SD } & \multirow{2}{*}{$\begin{array}{c}\text { Level } \\
\text { of } \\
\text { Mean }\end{array}$} \\
\hline & $\mathbf{N}$ & $\%$ & $\mathbf{N}$ & $\%$ & $\mathbf{N}$ & $\%$ & & & \\
\hline $\begin{array}{l}\text { Professional } \\
\text { Knowledge (PPP) }\end{array}$ & 0 & 0.0 & 10 & 5.0 & 190 & $\begin{array}{c}95 . \\
0\end{array}$ & 4.515 & 0.482 & High \\
\hline $\begin{array}{l}\text { Subject Content } \\
\text { Knowledge (PKS) }\end{array}$ & 0 & 0.0 & 27 & 13.5 & 173 & $\begin{array}{c}86 . \\
5\end{array}$ & 4.282 & 0.483 & High \\
\hline $\begin{array}{l}\text { Pedagogical } \\
\text { Content } \\
\text { Knowledge (PPK) }\end{array}$ & 0 & 0.0 & 12 & 6.0 & 188 & $\begin{array}{c}94 . \\
0\end{array}$ & 4.297 & 0.441 & High \\
\hline $\begin{array}{l}\text { Pedagogical } \\
\text { Technology } \\
\text { Knowledge (PTP) }\end{array}$ & 1 & 0.5 & 46 & 23.0 & 153 & $\begin{array}{c}76 . \\
5\end{array}$ & 4.128 & 0.642 & High \\
\hline $\begin{array}{l}\text { Professional } \\
\text { Values (NPK) }\end{array}$ & 3 & 1.5 & 6 & 3.0 & 191 & $\begin{array}{c}95 . \\
5\end{array}$ & 4.325 & 0.614 & High \\
\hline
\end{tabular}

The Relationship between Teachers' Understanding of Form Six Geography Topics and Their Competence

The relationship between teachers' understanding of form six geography topics and their competence was examined using the Pearson coefficient value as categorised by Cohen (1992): (a) values below 0.30 indicate a weak relationship strength, (b) values between 0.30 to 0.50 indicate a moderate relationship strength, and (c) values of more than 0.50 indicate a strong relationship (Table 8).

Table 8

Cohen's Classification of Relationship/Correlation Strength (1988)

\begin{tabular}{cc}
\hline r value & $\begin{array}{c}\text { Classification of Relationship/Correlation } \\
\text { Strength }\end{array}$ \\
\hline 0.10 until 0.29 & Weak \\
0.30 until 0.49 & Moderate \\
0.50 until 1.0 & Strong \\
\hline
\end{tabular}

Where $+1.00<\mathrm{r}<-1.00$

Table 9 shown the analysis of the correlation between teachers' understanding of form six geography topics and their competence showed a moderate significant relationship between the variables professional knowledge and understanding of form six geography topics with the value $\mathrm{r}(188)=.392, \mathrm{p}<.01$. There was also a relationship between professional values and understanding of form six geography topics with the value $\mathrm{r}(188)=.300, \mathrm{p}<.01$. As for subject content knowledge, pedagogical content knowledge and pedagogical technology knowledge, all showed a strong significant 
relationship with understanding of form six geography topics with values respectively of $\mathrm{r}(188)=.616, \mathrm{p}<.01, \mathrm{r}(188)=.574, \mathrm{p}<.01$ and $\mathrm{r}(188)=.532, \mathrm{p}<.01$.

In relation to this strong relationship between teachers' understanding of form six geography topics and subject content knowledge, Ahmad Yunus and Ab. Halim (2010) have argued that the understanding of subject content is important to ensure the effectiveness of the teaching of content knowledge. In addition, according to Mohammad Rusdi (2017), pedagogical content knowledge is a specific knowledge of teachers in terms of identifying their subject knowledge needs, because teachers' understanding of subject content is different from that of subject content experts. This is in accordance with the study's findings showing a strong relationship between pedagogical content knowledge and understanding of form six geography topics. The relationship between pedagogical technology knowledge and understanding of form six geography topics also showed a strong relationship in this study. This is in line with Koehler et al. (2013), who argued that teachers should creatively employ technology in learning and teaching sessions and 'think outside the box' at the same time as mastering their subjects.

The findings also showed professional knowledge to have a moderate relationship with understanding of form six geography topics. This indicates that professional knowledge needs to be enhanced in certain areas, such as planning lessons that can ensure students' performance reaches a high level and maintaining a learning environment that is conducive to teaching students effectively (Ibrahim et al, 2012). Overall, professional knowledge and values should be improved, because they show only a moderate relationship with teachers' understanding of form six geography topics, by improving teachers' preparation in the subjects they teach and diversifying the teaching and learning methods used to attract students' attention (Zaiha, 2014).

Table 9

Correlation between Teachers' Understanding of Form Six Geography Topics and Form Six Geography Teachers' Competence in Malaysia

\begin{tabular}{lccc}
\hline Variables & \multicolumn{2}{c}{$\begin{array}{c}\text { Teachers' } \\
\text { Understanding of Form } \\
\text { Six Geography Topics }\end{array}$} & \multirow{2}{*}{$\begin{array}{c}\text { Classification of } \\
\text { Correlation } \\
\text { Strength }\end{array}$} \\
\cline { 2 - 3 } & $\mathbf{r}$ & $\mathbf{p}$ & \\
\hline Professional Knowledge (PPP) & $.392^{* *}$ & .000 & Moderate \\
Subject Content Knowledge (PKS) & $.616^{* *}$ & .000 & Strong \\
Pedagogical Content Knowledge (PPK) & $.574^{* *}$ & .000 & Strong \\
Pedagogical Technology Knowledge & $.532^{* *}$ & .000 & Strong \\
(PTP) & $.300^{* *}$ & .000 & Moderate \\
Professional Values (NPK) & \multicolumn{3}{l}{} \\
\hline **significant at $p<0.01$ & & &
\end{tabular}

\section{Conclusions and Recommendations}

The results of this study show that in general, all variables of professional and pedagogical competencies were at high levels. This means that the teachers' 
understanding of their topic, as well as their professional knowledge, subject content knowledge, pedagogical content knowledge, pedagogical technology knowledge and professional values were at a satisfactory level they could be proud of. However, two aspects - professional knowledge and values - must be improved in order to achieve the ideal professional and pedagogical competencies of form six geography teachers in Malaysia, as indicated by the findings of only a moderate significant correlation between these two aspects and teachers' understanding of their topics. The professional knowledge acquired by teachers during learning at the preparatory level, i.e. university level, should be revisited in the form of regular workshops. Similarly, their professional values should also be enhanced, in terms of controlling their emotions in spite of the many challenges they and the teaching profession in general faces today in dealing with various student antics. The teaching profession is a noble one and it is therefore the duty of all teachers to maintain a high standard of professionalism in safeguarding their dignity and credibility.

\section{Acknowledgements}

This paper is based on the research project entitled 'Pembinaan Model Kompetensi Profesionalisme dan Pedagogi Guru Geografi Pra Universiti'. The authors would like to extend their gratitude to the Research Management and Innovation Centre (RMIC), Sultan Idris Education University (UPSI) for the University Research Grants (code: 2018-0040-107-01) that helped fund the research.

\section{References}

Ahmad Yunus, K., \& Ab. Halim, T. (2010). Pengetahuan Pedagogikal Kandungan (PPK) Pengajaran Akidah : Kajian kes guru cemerlang Pendidikan Islam. Journal of Islamic and Arabic Education, 2(2), 13-30. (In Malay)

Anuar, A. \& Nelson, J. (2015). Pengaruh kompetensi kemahiran guru dalam pengajaran terhadap pencapaian akademik pelajar dalam mata pelajaran sejarah. Jurnal Kurikulum \& Pengajaran Asia Pasifik, 3(2), 1-11. (In Malay)

Babbie, E. (1992). The practice of social research. CA: Wadsworth, Inc.

Chuah, B. K., Wan Rozali, W.H. \& Joseph, A. (2013). Isu pengajaran pembelajaran Geografi dan amalan refleksi kendiri dalam kalangan guru pelatih Institut Pendidikan Guru Malaysia. Seminar Pendidikan Sejarah dan Geografi 2013, 29 - 30 Ogos 2013, Universiti Malaysia Sabah, Malaysia. (pp 157-170). (In Malay)

Cohen, L., Manion, L. \& Morrison, K. (2000). Research methods in education (5th. ed.). London and New York: NY Routledge Falmer.

Hanifah, M., Shaharudin, I., Mohmadisa, H., Nasir, N., \& Yazid, S. (2015). Transforming sustainability development education in Malaysian schools through greening activities. Review of International Geographical Education Online ORIGEO, 5(1), 78-94.

Hasnah, I. \& Jamaludin, B. (2017). Kompetensi guru bahasa Melayu dalam menerapkan kemahiran berfikir aras tinggi dalam pengajaran dan pembelajaran. Jurnal Pendidikan Bahasa Melayu, 7(1), 56-66. (In Malay)

Ibrahim, S. S. \& Mohammed, S. (2012). Standard Kompetensi Guru Malaysia (Malaysia Teacher Competency Standard). Research Report. Universiti Malaya. Retrieved 
fromhttp://repository.um.edu.my/25208/1/STANDARD\%20KOMPETENSI\%20GURU \%20MALAYSIA\%20Saedah\%20Siraj\%20\%26\%20Mohammed\%20Sani\%20Ibrahim.pdf (In Malay)

Kandemir, A. M. (2016). The investigation of preservice mathematics and primary education teachers'reflective thinking levels according to some variables. Education Sciences (NWSAES), 10(4), 253-275. https://doi.org/10.12739/NWSA.2015.10.4.1C0646

Kementerian Pelajaran Malaysia. (2016). Etika dalam Profesion Keguruan. Putrajaya: Bahagian Pendidikan Guru, Kementerian Pelajaran Malaysia. (In Malay)

Kementerian Pendidikan Malaysia. (2009). Standard Guru Malaysia. (B. P. Guru, Ed.). Putrajaya: Kementerian Pendidikan Malaysia. (In Malay)

Kementerian Pendidikan Malaysia. (2017). Instrumen Standard 4: Pembelajaran dan Pemudahcaraan (Sekolah). Putrajaya: Kementerian Pendidikan Malaysia. (In Malay)

Koehler, M., Mishra, P. \& Cain, W. (2013). What is technological pedagogical content knowledge (TPACK). The Journal of Education, 193(3), 13-19.

Krejcie, R.V., \& Morgan, D.W. (1970). Determining sample size for research activities. Educational and Psychological Measurement, 30, 607-610.

Landell K. (1997). Management by menu. London: Wiley \& Sons Inc.

Lyle, S. M. \& Signe, S. M. (1993). Competence at work, models for superior performance. New York: John Wiley \& Sons, Inc.

Majlis Peperiksaan Malaysia. (2012). Peperiksaan Sijil Tinggi Persekolahan Malaysia. (STPM) Geografi. Sukatan Pelajaran dan Kertas Soalan Contoh. Kuala Lumpur: Majlis Peperiksaan Malaysia. Retrieved from https://www.moe.gov.my/images/pemberitahuan/standard\%20guru\%20malaysia\%20\%202009.pdf (In Malay)

Mohammad Rusdi, A. M. (2017). Pengetahuan teknologi pedagogi kandungan dan kreativiti pengajaran dalam kalangan guru Bahasa Arab di Malaysia. (PhD Thesis). Fakulti Pendidian, Universiti Malaya. (In Malay)

Mohd Faiz, M.Y. \& Jamal@Nordin, Y. (2016). Model pengukuran kompetensi kerja guru. International Seminar on Generating Knowledge Through Research, UUM-UMSIDA, $25-$ 27 October 2016, Universiti Utara Malaysia, Malaysia. Retrieved from http://ojs.umsida.ac.id/index.php/icecrs. (In Malay)

Mohd Faris, D., Mohmadisa, H. \& Mohd Suhaily Yusry, C. N. (2013). Geographic literacy among university student's in Peninsular Malaysia. Geographic Education in Malaysia. Department of Geography and Environment.

Nazli, G. (2009). The problems of geography education and some suggestions. Kuram ve Uygulamada Ĕgitim Bilimleri / Educational Sciences: Theory \& Practice, 9(2), 757-768

Rohayati, I., Ahmad Fauzi, M. A., \& Othman, T. (2012). Hubungan antara kompetensi guru, sokongan dan prasarana sekolah dengan sikap guru terhadap penggunaan teknologi maklumat dan komunikasi dalam pengajaran dan pembelajaran. Jurnal Pendidikan Sains \& Matematik Malaysia, 2(1), 51-64. (In Malay)

Samuel, A., Ojih, E. \& Linus, U. (2014). Competency gaps among geography teachers in the teaching of geography mapwork in secondary schools in Kogi Stat. Journal of Education 
Hanifah, M., Mohmadisa, H., Yazid, S, Nasir, N., Balkhis, N., S. (2019) / Professional and pedagogical....

and Practice, 5(25), 41-49.

Schiro, M. S. (2007). Curriculum theory conflicting visions and enduring concerns. (1 st ed). USA: Boston College.

Shulman. L. (1987) Knowledge and teaching: Foundations of the new reform. Harvard Educational Review, 57(1), 1-23.

Suseela, M., \& Sim, K. H. (2010). Teacher perspectives of school-based assessment in a secondary school in Kuala Lumpur. Procedia Social and Behavioral Sciences, 9, 11701176.

Wan Mohd Zahid, M. N. (1991). Reformasi Pendidikan dan Kurikulum Bersepadu Sekolah Menengah: Isu dan cabaran, reformasi pendidikan di Malaysia. (M. I. Jauzi, Ed.). Kuala Lumpur: Nurin Enterprise. (In Malay)

Zaiha Nabila, M. H. (2014). Kompetensi guru dalam pengajaran amali reka bentuk dan teknologi di sekolah rendah Daerah Batu Pahat. (Master Thesis). Fakulti Pendidikan Teknikal dan Vokasional, Universiti Tun Hussein Onn Malaysia. (In Malay)

\section{Biographical Statements}

Mahat HANIFAH is a senior lecturer in the Department of Geography \& Environment, Faculty of Human Science at Universiti Pendidikan Sultan Idris (UPSI) Malaysia. She previously taught at senior high school level for 11 years, 6 years at teacher training institutes and joining the academic faculty at the University in 2014. Her major fields of research include sustainable education practices and behaviour.

Hashim MOHMADISA is a senior lecturer in Department of Geography \& Environment, Faculty of Human Science at Universiti Pendidikan Sultan Idris (UPSI) Malaysia. His major fields of research include Hydrology, Physical Geography and Environmental Management.

Saleh YAZID is a senior lecturer in Department of Geography \& Environment, Faculty of Human Science at Universiti Pendidikan Sultan Idris (UPSI) Malaysia. His major fields of research include sustainable Urban Geography Urban Conservation Cultural and Heritage Tourism Urban Studies.

Nayan NASIR is a senior lecturer in Department of Geography \& Environment, Faculty of Human Science at Universiti Pendidikan Sultan Idris (UPSI) Malaysia. His major fields of research include geographic information systems, GIS, remote sensing, remote sensing, GIS Online, Business Information System, physical geography, human geography, mangroves, coral reefs, ecosystems, ecology, coastal, coastal zones.

Norkhaidi SAIYIDATINA BALKHIS is a postgraduate student undergoing $\mathrm{PhD}$ in Department of Geography \& Environment, Faculty of Human Science at Universiti Pendidikan Sultan Idris (UPSI) Malaysia and also a Research Assistant for this project. Her research are on environmental literacy and numeracy also development of index. 